\title{
SPRAY SPECTRA, DEPOSITION AND SEDIMENTATION CHARACTERISTICS FOR LOW PRESSURE LIQUID ATOMIZERS
}

\author{
*Sehsah, E. M. E.
}

ABSTRACT

The focus of this investigation was on assessing the feasibility of the evaluation new developing nozzles that will target and spray the biological pest control materials and herbicides. As well as comparing the spray characteristics for external mixing twin fluid nozzles with the low liquid atomizers motorized Backpack mistblower and Proptec ${ }^{T M}$ rotary atomizer. The Stihl SR 340 Powerful knapsack Mist-blower $2.6 \mathrm{~kW}$, rotary atomizer, Ledebuhr Industries, Inc. 11429 Upton Road Bath, Michigan-48808) and five developed an external mixing twin fluid (EMTF) nozzles were tested under laboratory condition to measure the spray droplet spectra, the spray deposition and sedimentation. Droplet size spectra produced by three atomizers, mistblower, rotary cage and EMTF nozzles were measured using the Malvern laser (particle size analyzer). The three atomizers were tested at flow-rate $0.5 \mathrm{l} \mathrm{min}{ }^{-1}$ and $1 \mathrm{l}$ min $^{-1}$. As well as, the motorized Backpack Mistblower and Proptec ${ }^{\mathrm{TM}}$ rotary cage atomizer were tested under four levels for rotational speed. The rotational speeds for Proptec ${ }^{T M}$ Rotary cage atomizer were 3000 r.p.m, 3500 r.p.m 4600r.p.m and 5000 r.p.m; and its were 3000 r.p.m, 4000 r.p.m, 5000 r.p.m and 6000 r.p.m for Backpack Mistblower. On the other hand, the five EMTF nozzles were tested at $150 \mathrm{kPa}$ air pressure. The three atomizers was operated at low various pressures, five external twin-fluid nozzles at $30 \mathrm{kPa}$, mistblower at $28 \mathrm{kPa}$ and rotary atomizer at $90 \mathrm{kPa}$ liquid pressures. The different atomizers were compared by using the spray spectra, spray deposition and spray sedimentation parameters. The result indicated that, the rotary cage atomizer generally gave droplet spectra with lower $D_{\text {vo.1 }}, D_{\text {vo.5 }}$ and $D_{\text {vo.9 }}$ values than the Backpack motorized Mistblower and the five EMTF air-shear nozzles. The Proptec $^{T M}$ rotary cage atomizes gave very fine droplets spectra with higher deposition than the Backpack mistblower and the five EMTF airshear nozzles. The spray spectra D0.1, Dv0.5 and D0.9 for EMTF nozzles 
at $0.5 \mathrm{l} \mathrm{min}^{-1}$ flow rate were $42.7 \mu \mathrm{m}, 100.9 \mu \mathrm{m}$ and $195.4 \mu \mathrm{m}$; and 46.7 $\mu \mathrm{m}, 107.0 \mu \mathrm{m}$ and $206.1 \mu \mathrm{m}$ for both $\mathrm{N} 3$ and $\mathrm{N} 5$ respectively. The deposition percentage for N3 (Lechler FT 5 - 608 + Lechler LU 120-015 POM) and N5 (Lechler FT 5 - $608+$ Tee Jet XR8004 VK) were $57.7 \%$

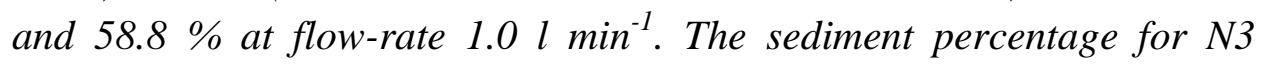
(Lechler FT 5 - 608 + Lechler LU 120-015 POM) and N5 (Lechler FT 5 $608+$ Tee Jet XR8004 VK) were $16.3 \%$ and $14.6 \%$ at flow-rate $0.5 l$ $\mathrm{min}^{-1}$.

Keywords: Spray spectra, Nozzles, Deposition, Sedimentation

\section{INTRODUCTION}

$\mathrm{P}$ esticides are widely used in agriculture for the management of pests (weeds, insects or pathogens). They are generally applied as a spray to cover the target (e.g. an insect, leaf surfaces or part of a plant) with pesticide-laden droplets. Spray may, however, be lost to nontarget areas within a crop through deposition on to the soil or on nontarget plant surfaces. By selecting and using spray equipment and techniques that maximize deposition of pesticides onto the target it is possible to both maximize the effectiveness of the pesticide application and reduce the amount of off-target deposition and damage. Application of Post Emergence herbicides and Bio-pesticides (living organisms) are becoming an ever-increasing complex phase of crop production. More information about how to use the latest nozzle technologies to apply herbicides or Bio-pesticides for Post Emergence control of grasses and broadleaves is paramount for achieving optimum control of the undesired pests. The complexity of the Post Emergence application process is exemplified as recent nozzle technology and it is placing an increased emphasis on keeping the drift potential at a minimum. Teske, et al. (2005) indicated that the droplet size information, in particular the volume fraction in smaller droplet size (which tend to be more prone to drift) and the larger droplet size (which fall largely with the application area), is critical to forestry and agricultural application. In addition, the specific levels of spray material in specific droplet size ranges must be deposited to achieve efficacy.

Spray droplets are formed by toothed, grooved, spinning discs or wire mesh cage. Centrifugal force generated by the spinning action causes the 
release of spray droplets. Rotary nozzles reduce the range of droplet sizes being applied, so very small and very large droplets are avoided. The Micron-air Mini Atomizer is an example of the rotary atomizer that is capable of 2000 to $12000 \mathrm{rpm}$. By adjusting the fan blade, the rotational speed is changed and droplet size can be adjusted from 80 to 1,000 microns. The measurements carried out by many workers on many different types of rotary atomize all indicate that mean droplet size diminishes with increasing rotational speed and increases with liquid flow rate and surface tension. Gebhardt et al. (1985) studied the comparison of a rotary atomizer to a fan nozzle for herbicide application. In addition, the large droplets at the $56 \mathrm{l} \mathrm{ha}^{-1}$ with the rotary atomizer produced larger droplets than other methods of application because the droplet generation rate (cup peripheral velocity and number of teeth) was the same for the 28 and $561 \mathrm{ha}^{-1}$ rotary atomizer treatments. The large droplets at the $561 \mathrm{ha}^{-1}$ volume rate also affected the amount of spray contained in small droplets. For droplets less than $204 \mu \mathrm{m}$ in diameter, the volume content was about the same for the $281 \mathrm{ha}^{-1}$ volume rate with the rotary atomizer as for the $187 \mathrm{l} \mathrm{ha}^{-1}$ volume rate with the flat-fan nozzle. While there was a very significant difference in the volume content in small droplets between the rotary atomizer and the flat-fan nozzle, volume of no more than $3.7 \%$ in small droplets for fan nozzles hardly seems enough to affect herbicide activity.

Peterson and Hogmire (1994) investigated the tunnel sprayer for dwarf fruit trees and tested the Proptec ${ }^{\mathrm{TM}}$ units (1A), which had the upper and lower pair of air jets converging in center of the tree. The Proptec ${ }^{\mathrm{TM}}$ unit (1A) in the center of the tree gave the lowest average deposition and second worst uniformity $(111 \% \mathrm{CV})$ under all testes. Spray was deposited mainly in the periphery of the tree with almost no deposition in the center of the tree.

Bateman and Alves (2000) carried out a number of spray measurements and discuss the droplet size distributions for Backpack mistblower, with an optimum thought to be between $40-120 \mu \mathrm{m}$, depending on the formulation used. Smaller droplet spectra are possible using oil formulations due to reduced evaporative rates as compared to aqueous 
formulations. If droplets are too small, then the risk of losses due to drift and convection increases. In addition, small droplets can lack the necessary momentum to reach the desired height when spraying. If the droplets are too large then a large proportion will settle out onto the ground, or worse, the operator. Therefore, the ideal sprayer will produce a narrow spectrum of droplet sizes within a desired size range. Siegfried and Holliger (1996) report that about 40 - $50 \%$ of applied products are deposited on leaves and fruit with axial-fan or cross-flow fan sprayers while deposits on dormant trees averaged about $24 \%$. Pergher and Gubiani (1995) measured the effect of spray application rate and vineyard foliage density on spray distribution. Increasing spray application rate and air jet volume produced greater ground deposits and less foliage deposits. Ground deposits were about $35 \%$ of applied spray for 33 and 42 gal/acre application rates; and 41 to $49 \%$ for 70 and 78 gal/acre application rates. Off-target drift ranged from 6.5 to $10.5 \%$ for low air output $\left(424.8 \mathrm{~m}^{3}\right.$ $\mathrm{min}^{-1}$ ) and from 7.8 to $19.8 \%$ for high air volume $\left(509.7 \mathrm{~m}^{3} \mathrm{~min}^{-1}\right)$. Greatest deposition on foliage (about $55 \%$ of amount sprayed) was for low spray volume and low jet air flow-rate.

Also, Knewitz et al. (2000) cited that biological efficacy is the most important requirement of pesticide application beside the drift reducing effects of coarse droplet application. When spraying a contact fungicide (Delan) even reduced, dose rates did not show differences in efficacy between coarse and fine droplet application. This experience is supported by other investigators and provides evidence for further investigations and the chance to reduce spray drift in fruit production (Frießleben \& Oeser, 2000; Frießleben, 2001; Heinkel \& Lange, 2000; Schmidt \& Funke, 2001; Walklate, 1992). The investigated target organisms are difficult to control and require good initial deposits, uniform distribution and coverage.

Salyani and Hoffmann (1996) studied the optimization of deposition efficiency for air blast sprayers. He used different combinations of the nozzle disc-core sizes, number of nozzles and ground speed. Spray targets were positioned at several spatial locations in open space and deposition was determined by copper calorimeter. Allover, deposition increased as speed increased or core size decreased. 
The main objectives of this current study are:

To investigate and evaluate the spray spectra from an external mixing twin fluid nozzles by comparing with the low liquid pressure Backpack mistblower and single hydraulically driven cage rotary atomizers (Proptec).

To measure the sedimentation and deposition for the three low pressure liquid atomizers Backpack mistblower, rotary cage atomizer and EMTF nozzles.

\section{MATERIALS AND METHODS}

\section{Backpack Motorized Mistblower}

The Stihl 340 was selected (Andreas Stihl AG \& Co., Waiblingen, Germany) for future trial work since it appears to maximize in the desired band over a wide range of flow rates. The capacity of the SR tank is 14 Liters for application of plant control agents, seeds, wet chemicals, granulated materials and bio-pesticides in horticultural and contracting applications. The engine and fan unit are attached by anti-vibration mountings to a knapsack frame, designed to allow the spryer to stand upright on the ground. The frame, with stapes, also carries a pesticide tank, spray deliver tube, fuel tank and an air delivery hose. The Backpack mistblower operated at rotational speed 6540 r.p.m. Some air is fed from the fan into the spray tank and usually ducted to the base of the whole filter to provide low pressure $(25 \mathrm{kPa})$ to deliver the spray liquid to the nozzle. The air pressure is most important if the standard air delivery tube is pointed upwards, when the nozzle may be above the level of liquid in the tank. A nozzle mounted at end of the air delivery tube. A fixed restrictor controls the volume of spray liquid emitted. The power requirement to drive the mist-blower sprayer was $2.6 \mathrm{~kW}$ at maximum operation conditions. The Stihl SR 340 Powerful knapsack mist-blower was tested under laboratory conditions. The flow-rate was controlled to obtain the different tests of the mist-blower Figure 4 illustrates the SR 340 Powerful knapsack mist-blower and its position to measure the droplet size under laboratory conditions.

Proptec $^{\mathrm{TM}}$ rotary atomizer 
The rotary atomizer or controlled droplet applicator (CDA) has been used for years in aerial application but is a relative new device for ground application. The rotary atomizer nozzles form the spray by using centrifugal force at a rotating disk of wire cage rather than forcing the liquid through a nozzle orifice. The rotary atomizer (Proptec ${ }^{\mathrm{TM}}$, Ledebuhr Industries, Inc. 11429 Upton Road Bath, Michigan-48808) manufactured from the following component, rugged stainless steel welded frame with protective air intake grate, the center axial fane, high strength fiberglass protective and hydraulic gear motors. The gear motor rotating at 5000$5500 \mathrm{rpm}$ and the rotary atomizer produces a narrow spectrum of droplets averaging 60 to 120 microns. In addition, blade angle could be manually adjustable. The liquid distribution system consisted of a metal liquid feed channel with holes leading to a series of grooves on the insides of the vanes between the slots. The open-ended design allowed the cage to act as a small centrifugal fan. Figure 1 indicates the construction of rotary atomizer unit.

The power requirement to drive the one unit of Proptec ${ }^{\mathrm{TM}}$ rotary atomizer could be indicated that the average hydraulic power for around $4 \mathrm{~kW}$ but for four units, it will be more than $20 \mathrm{~kW}$. The completely spray machine for Proptec atomizer was developed by Sehsah 2005 in Germany that derived with the hydraulic power from the tractor.

\section{External mixing twin fluid nozzles}

The principle of the external mixing twin fluid nozzle is the injection of a liquid sheet into an air sheet, both produced by tongue nozzles. At the merging line, the high-speed air stream will disintegrate the liquid sheet and produce droplets (Sehsah and Kleisinger, 2007 and Sehsah, 2005). The nozzle of air Lechler FT 5-608 was constructed with five different liquid nozzles Tee Jet TT11005, Lechler AD120-04 C, Lechler LU 120015 POM, Tee Jet DG 8003 VS and Tee Jet XR8004 VK to obtain the External mixing twin fluid nozzles as shown in table 1. The External mixing fluid nozzles need two different power sources to drive, one for the liquid nozzles ( water pump) and the second for air nozzle ( the compressor). The power requirement for driving the external mixing twin 
fluid nozzles was measured by the power meter. The total power requirement was calculated by using the following equations:

$$
\text { Powertal } \left._{\text {total }}=\boldsymbol{P}_{\text {comp }}+\boldsymbol{P}_{w} \ldots \ldots \ldots \ldots \text {..... }\right]
$$

Were:

$\mathrm{P}_{\text {comp }}$ is the required power to drive the compressor

$\mathrm{P}_{\mathrm{w}} \quad$ power required to drive the water pump

$\mathrm{P}_{\text {tota }}$ total power

The total power requirement was $1.8 \mathrm{~kW}$ for both different power sources to drive the compressor and water pump.
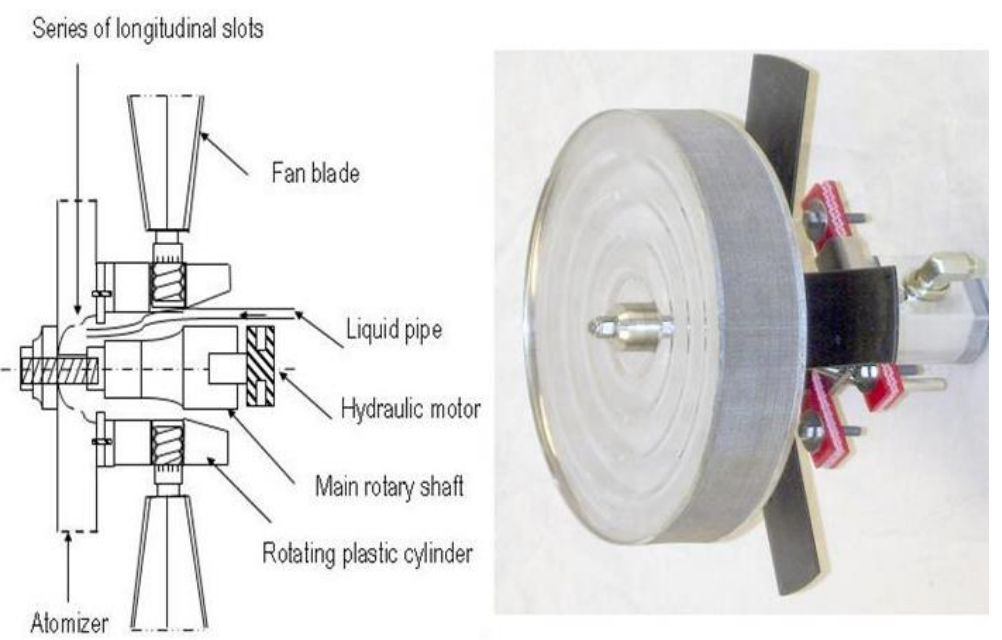

Fig. 1: The diagram of the main parts of the Proptec ${ }^{\mathrm{TM}}$ rotary atomizer

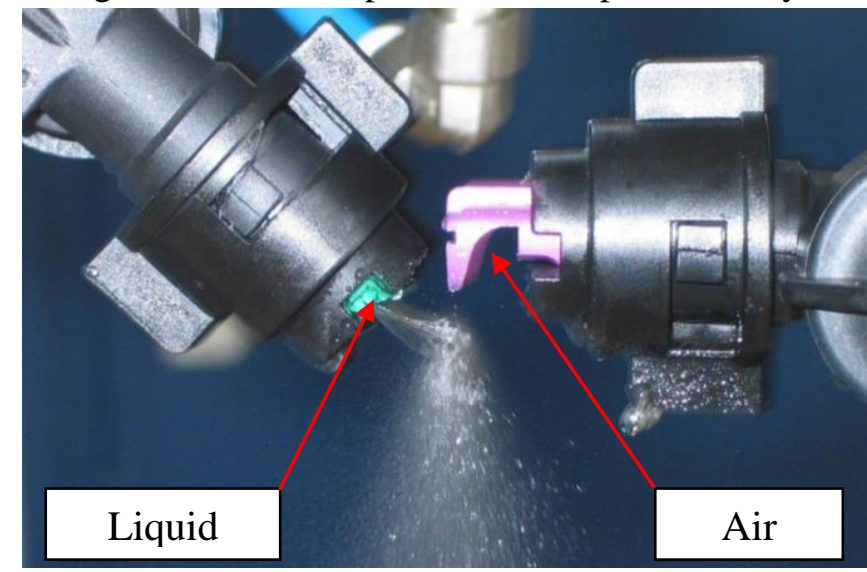

Fig. 2: The combination of a tongue nozzle (Lechler FT5.0) for the air and a LU 110-015 for the liquid. 


\section{Procedure and measurements}

\section{Measurement of droplet size spectra}

The above-mentioned three different techniques spray atomizers were tested under Laboratory condition to measure the spray spectra and spray deposition. The Malvern instrument Master Particle Sizer (Malvern Instruments, GB) at the laboratory of Federal Research Center Geisenheim, Germany, measured the droplets spectra of the spray from, Stihl SR 340, Proptec ${ }^{\mathrm{TM}}$ rotary atomizer and different combination of the external mixing twine-fluid nozzles. The two different levels of flow rate $0.51 \mathrm{~min}^{-1}$ and $11 \mathrm{~min}^{-1}$ of spray liquid were adjusted for each atomizer before starting the experiments. During the laser diffraction measurement, particles are passed through a focused laser beam. These particles scatter light at an angle that is inverses proportional to their size. The angular intensity of the scattered light is then measured by a series of photosensitive detectors. The focal length $800 \mathrm{~mm}$ and beam length 400 $\mathrm{mm}$ for Malvern particle analyzer instrument adjusted to measure the spray characteristics for the three liquid atomizers in laboratory test of agricultural mechanization, Geisenheim, Germany. The droplet sizing was done using a Malvern 'Spraytec' laser particle size analyzer (www.malvern.co.uk). The sprayers were operated at full engine speed, using manufacturer's recommended fuel mix, to project the water spray through a laser beam to measure droplet size as shown in Figure 3. The different types N1, N2, N3, N4, and N5 of EMTF nozzles were compared at $150 \mathrm{kPa}$ air pressures and. The co-angling (injection angles) nozzle were $45^{\circ}$ degree.

\section{Measuring the air velocity from different atomizers}

The FC012-Micromanometer was used to measure the volume and air velocity at $2 \mathrm{~cm}$ outlet distance from the different atomizers, mist-blower, Proptec $^{\text {TM }}$ and FT 5-608 nozzle in EMTF nozzles. Table 2 displays the result values of the measuring air volume and velocity at $2 \mathrm{~cm}$ outlet distance from the three atomizers mist-blower, Proptec ${ }^{\mathrm{TM}}$ and FT 5-608 nozzle. 


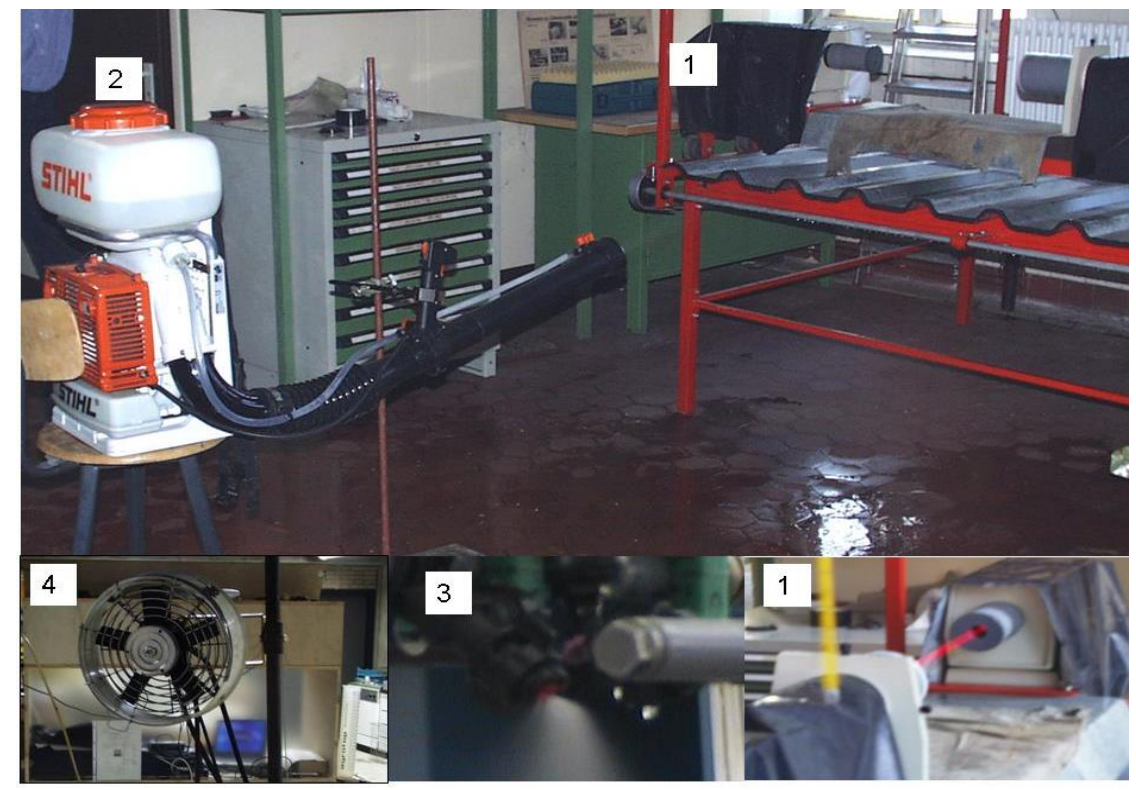

1- The Malvern 'Spraytec' laser particle size analyzer $\quad$ 2-Stihl mistblower
3- EMTF nozzles

Fig. 3: The Malvern 'Spraytec' laser particle size analyzer to measure the droplet spectrum from different low liquid atomizers

Table 1.The combinations of the external mixing twin fluid (EMTF) nozzles

\begin{tabular}{c|c|c}
\hline \multirow{2}{*}{ EMTF nozzles } & \multicolumn{2}{|c}{ Co-Nozzles } \\
\cline { 2 - 3 } & Air nozzles & Liquid nozzles \\
\hline N 1 & Lechler FT 5 - 608 & Tee Jet TT11005 \\
N 2 & Lechler FT 5 - 608 & Lechler AD120-04 POM \\
N 3 & Lechler FT 5 - 608 & Lechler LU 120-015 \\
& & POM \\
N 4 & Lechler FT 5 - 608 & Tee Jet DG 8003 VS \\
N 5 & Lechler FT 5 - 608 & Tee Jet XR8004 VK \\
\hline
\end{tabular}

Table 2: The air volume and air velocity requirement for different low liquid atomizers

\begin{tabular}{lcc}
\hline \multicolumn{1}{c}{ Atomizers } & $\begin{array}{c}\text { Air velocity } \\
\mathrm{m} / \mathrm{s}\end{array}$ & $\begin{array}{c}\text { Air flow rate } \\
\mathrm{m}^{3} \mathrm{~h}^{-1}\end{array}$ \\
\hline Motorized Backpack Mistblower @ 3000 r.p.m & 51.3 & 621 \\
Motorized Backpack Mistblower @ 6000 r.p.m $^{\mathrm{TM}}$ rotary cage atomizer @ 3000 r.p.m & 90.6 & 892 \\
Proptec $^{\mathrm{TM}}$ rotary cage atomizer @ 5000 r.p.m & 26.4 & 2010 \\
Proptec $^{2}$ & 5300 \\
External mixing twin fluid (EMTF) nozzle at & 54.3 & 383 \\
$150 \mathrm{kPa}$ air pressure & & \\
\hline
\end{tabular}




\section{Measuring the deposition and sedimentation}

The three atomizers, Backpack mistblower, Proptec rotary atomizer and five EMTF nozzles were fixed at one meter height from the ground. As well as, the flow rate was adjusted at the above-mentioned values in the spray spectra tests. The Petri dishes were distributed in three rows in the ground of the roam test as shown in figure 4 . The filter papers were fixed at the vertical bars. The samples were collected by cutting $10 \mathrm{~cm}$ of the filter papers from the vertical bars and after the treatments; the samples were putted into the Petri dishes to measure the deposition. The sedimentation samples were collected after every treatment. BSF fluorescent dye was used at a concentration of $0.1 \%$. After each application, the Petri dishes were covert and stored in a dark cardboard box. The sample from the sprayer's tank was collected for calibration of the measurement. The peristaltic pump added the $100 \mathrm{ml}$ of deminized water to each Petri dish to wash the tracer from both paper samples and Petri dishes. The dishes were placed on an oscillating conveyor belt to wash all dye deposits from the interior surface of each Petri dish as shown in figure 5. The tracer concentration in the washing solution was determined using the Fluorimeter Perkin Elmer. The tank sample was used to calibrate the measurement. The percent recovery calculations for the field data were based on the average fluorometrically determined deposit as a percentage of the calibrated volumetric application volume rate. The same equation for calculating of deposit was used to estimate the sediment by using other values for tracer concentration.

Determination of deposit was performed with the following equations; the symbols used are defined in the notation.

\begin{tabular}{|c|c|c|}
\hline $\mathrm{D}_{\mathrm{e}}=(\mathrm{C}$ & $\left.* \mathrm{c}_{i} . \mathrm{f} . * \mathrm{q}\right) /\left(\mathrm{c}_{i i} . \mathrm{s}^{*} \mathrm{a}^{*} \mathrm{~m}\right)$ & {$\left[\mu \mathrm{g} \mathrm{cm}^{-2}\right]$} \\
\hline R.D $=$ & $(\mathrm{D} / \mathrm{T})^{*} 100$ & {$[\%]$} \\
\hline $\mathrm{T} 1=$ & $* \mathrm{~V} / 10$ & [ ] \\
\hline $\mathrm{T}=\mathrm{T} 1$ & 100 & [ ] \\
\hline $\mathrm{D}_{\mathrm{e}}$ & Deposition & {$\left[\mu \mathrm{g} \mathrm{cm}^{-2}\right]$} \\
\hline R.D & Relative deposition & {$[\%]$} \\
\hline $\mathrm{C}$ & Spectrophotometer value (concentration) & [ ] \\
\hline $\mathrm{c}_{i} . \mathrm{f}$ & Correcting factor, & {$[1]$} \\
\hline
\end{tabular}




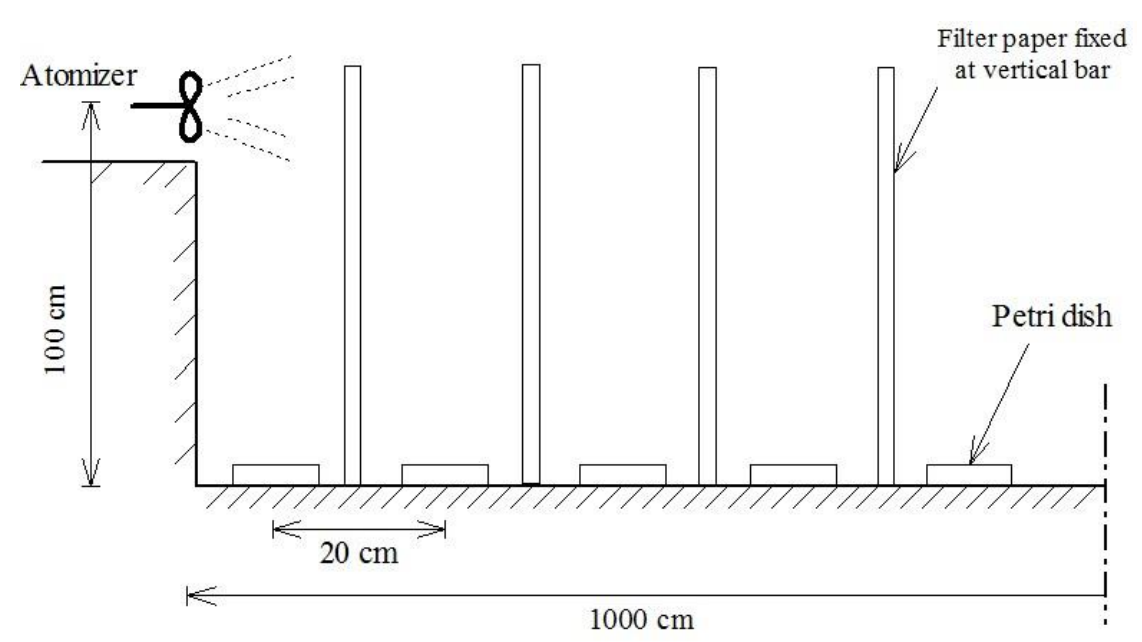

Fig. 4: The diagram for deposition and sedimentation tests for three lowpressure atomizers

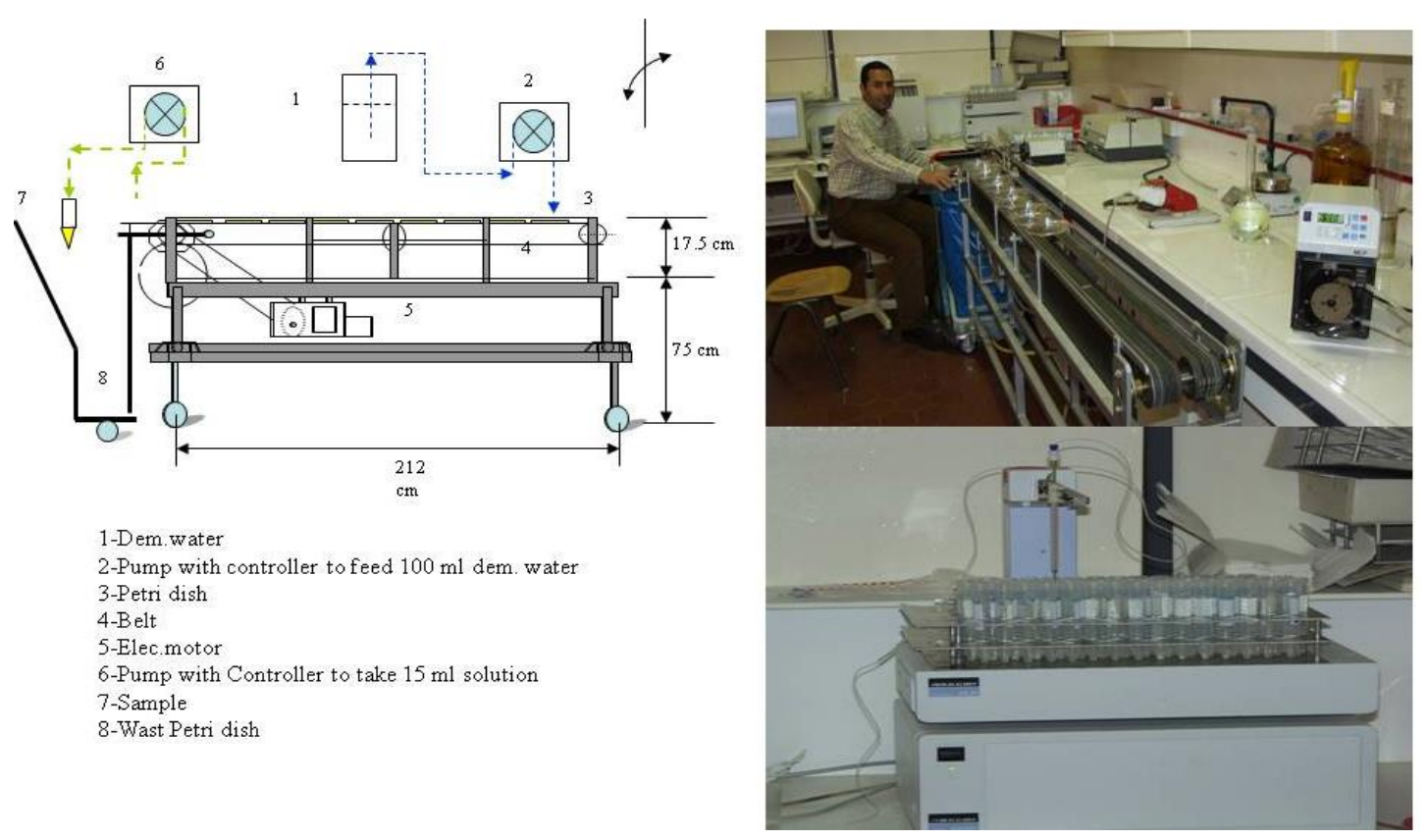

Fig. 5: Display the laboratory facilities instruments (LS 30 Fluorescence Spectrometer) to measure the spray deposition from different atomizers. 


$\begin{array}{lll}\mathrm{q} & \text { Washing -up liquid quantity } & {\left[40 \mu \mathrm{g} \mathrm{l}^{-1}\right]} \\ \mathrm{a} & \text { Ash } & {\left[5000 \mu \mathrm{g} \mathrm{l}^{-1}\right]} \\ \mathrm{c}_{i i} \mathrm{~s} & \text { Collector surface area } & {\left[15 \mathrm{~cm}^{2}\right]} \\ \mathrm{m} & \text { Measuring range factor } & {[1]} \\ \mathrm{T} & \text { Tracer application rate } & {\left[\mu \mathrm{g} \mathrm{l}^{-1}\right]} \\ \mathrm{c}_{i i} & \text { Tracer concentration } & \\ \mathrm{V} & \text { Volume application rate } & {\left[1 \mathrm{ha}^{-1}\right]} \\ \mathrm{T} 1 & \text { Tracer application rate } & {\left[\mathrm{g} \mathrm{cm}^{-2}\right]}\end{array}$

\section{RESULTS AND DISCUSSIONS}

The statistical software package used in the analysis was Origin ${ }^{\circledR} 7 \mathrm{G} \mathrm{SR} 1$ version 7.0303 (OriginLab Corporation, One Roadhouse Plaze, Northampton, MA 01060 USA). Statistical analysis was performed by applying analysis of variance (ANOVA). The main factor of treatments for both Backpack mistblower and rotary cage atomizer was the rotationnel speed. On the other hand, the main factor was the type of nozzles for the EMTF nozzles. All experimental were treated at two flow rate levels $0.51 \mathrm{~min}^{-1}$ and $11 \mathrm{~min}^{-1}$

\section{Spray spectra for different atomizers}

The results indicated that the increasing of rotational speed for both motorized Backpack Mistblower and Proptec ${ }^{\mathrm{TM}}$ hydraulic rotary atomizers tends to reduce the droplets size as shown in tables 3 and 4. As well as the increasing of rotational speed gave the very fine spray spectra at two flow rate conditions $0.51 \mathrm{~min}^{-1}$ and $1.01 \mathrm{~min}^{-1}$. The spray spectra values for Motorized Backpack mistblower at flow rate $0.51 \mathrm{~min}^{-1}$ and 6000 r.p.m maximum rotational speed were $26.8 \mu \mathrm{m}, 77.8 \mu \mathrm{m}$ and 133.2 $\mu \mathrm{m}$ for $\mathrm{D}_{0.1}, \mathrm{D}_{\mathrm{v} 0.5}$ and $\mathrm{D}_{0.9}$, respectively. On the other hand, it's found that the flow rate was non-significant effect on the spray spectra for Backpack Mistblower as shown in table 3.

As well as, the spray spectra for Proptec ${ }^{\mathrm{TM}}$ rotary atomizer at maximum rotational speed 5000 r.p.m and $0.51 \mathrm{~min}^{-1}$ flow rate were $35.5 \mu \mathrm{m}, 62.3$ $\mu \mathrm{m}$ and $108.1 \mu \mathrm{m}$ for $\mathrm{D}_{0.1}, \mathrm{D}_{\mathrm{v} 0.5}$ and $\mathrm{D}_{0.9}$, respectively. In addition, it was non-significant effect of the flow rate on the spray spectra for Proptec rotary cage atomizer as shown in table 4 . 
On the other hand, the type of nozzles in EMTF nozzles were the main factors that affecting on the spray spectra. The EMTF nozzle (N3 and N5) tends to produce the very fine spray spectra $\mathrm{D}_{0.1}, \mathrm{D}_{\mathrm{v} 0.5}$ and $\mathrm{D}_{0.9}$ compared with the N1, N2, N4 EMTF nozzles as shown in table 5. This result mean that the EMTF nozzles may be produced the spray spectra as the same of spray characteristics for both motorized mistblower and hydraulic rotary atomizers with low energy. Therefore, the power requirements for the three atomizers were $4,2.6$ and $1.8 \mathrm{~kW}$ for Proptec ${ }^{\mathrm{TM}}$ rotary atomizer, Mistblower and EMTF nozzles respectively.

On the other hand, the flow rate was a significant effect on the spray spectra $\mathrm{D}_{0.1}, \mathrm{D}_{\mathrm{v} 0.5}$ and $\mathrm{D}_{0.9}$ for all five EMTF nozzles. The spray spectra $\mathrm{D}_{0.1}, \mathrm{D}_{\mathrm{v} 0.5}$ and $\mathrm{D}_{0.9}$ for EMTF nozzles at $0.51 \mathrm{~min}^{-1}$ flow rate were 42.7 $\mu \mathrm{m}, 100.9 \mu \mathrm{m}$ and $195.4 \mu \mathrm{m}$; and $46.7 \mu \mathrm{m}, 107.0 \mu \mathrm{m}$ and $206.1 \mu \mathrm{m}$ for both N3 (Lechler FT 5 - 608 + Lechler LU 120-015 POM) and N5 (Lechler FT 5 - $608+$ Tee Jet XR8004 VK), respectively.

It's clearly that, the all five EMTF nozzles gave very fine spray spectra at low flow rate $0.51 \mathrm{~min}^{-1}$. This means also, it was no different spray spectra values between the EMTF nozzles, motorized mistblower and hydraulic rotary atomizers at low flow rate $0.51 \mathrm{~min}^{-1}$.

In Table 6, the Proptec ${ }^{\mathrm{TM}}$ rotary atomizer gave a very fine spray spectra compared with the motorized mistblower and the five EMTF nozzles. On the other hand, the EMTF nozzles may be suitable spray techniques for the Bio-pesticides therefore; its have produced the suitable droplets for Bio-pesticides spatially for the microorganisms Bio-pesticides (Sehsah, 2005 and Sehsah \& Kleisinger 2007). In table 6, the spray spectra $D_{\mathrm{v} 0.5}$ at flow rate $11 \mathrm{~min}^{-1}$ were $184.0 \mu \mathrm{m}, 141.6 \mu \mathrm{m}, 113.1 \mu \mathrm{m}, 145.1 \mu \mathrm{m}$ and $114.1 \mu \mathrm{m}$ for EMTF nozzles N1, N2, N3, N4, and N5, respectively. On the other hand, the Mistblower and Proptec rotary cage produced a very fine droplets compared with the all five EMTF nozzles at $11 \mathrm{~min}^{-1}$. In addition, the EMTF nozzles N3 (Lechler FT 5 - 608 + Lechler LU 120-015 POM) and N5 (Lechler FT $5-608+$ Tee Jet XR8004 VK) produced the droplets size $\mathrm{D}_{0.1}, \mathrm{D}_{\mathrm{v} 0.5}$ and $\mathrm{D}_{0.9}$ nearly the spray spectra that produced by the mistblower and Proptec rotary cage atomizers.

In table 7 display, the effect of flow rate for all atomizers on the spray spectra and it was non-significant effect on the droplets size $\mathrm{D}_{0.1}, \mathrm{D}_{\mathrm{v} 0.5}$ and 
$\mathrm{D}_{0.9}$. It means also, it was no different between the spray spectra for all three low-liquid atomizer Mistblower, Proptec rotary cage and EMTF nozzles under this treatment conditions.

Table 3: Measured spray spectra characteristics for different testes of Mist-blower different flow rate

\begin{tabular}{ccccc}
\hline Treatment & $\begin{array}{c}\text { Flow-rate, } \\
1 \mathrm{~min}^{-1}\end{array}$ & $\begin{array}{c}\mathrm{D}_{\mathrm{v} 0.1} \\
\mu \mathrm{m}\end{array}$ & $\begin{array}{c}\mathrm{D}_{\mathrm{v} 0.5} \\
\mu \mathrm{m}\end{array}$ & $\begin{array}{c}\mathrm{D}_{\mathrm{v} 0.9} \\
\mu \mathrm{m}\end{array}$ \\
\hline Mistblower (3000 r.p.m) & 0.5 & 40.8 & 102.7 & 179.7 \\
Mistblower (3000 r.p.m) & 1.0 & 40.2 & 99.5 & 170.6 \\
Mistblower (4000 r.p.m) & 0.5 & 38.2 & 93.9 & 165.6 \\
Mistblower (4000 r.p.m) & 1.0 & 36.1 & 91.7 & 163.1 \\
Mistblower (5000 r.p.m) & 0.5 & 33.9 & 90.7 & 158.8 \\
Mistblower (5000 r.p.m) & 1.0 & 34.3 & 81.7 & 142.3 \\
Mistblower (6000 r.p.m) & 0.5 & 26.8 & 77.8 & 133.2 \\
Mistblower (6000 r.p.m) & 1.0 & 33.1 & 77.5 & 125.5 \\
\hline
\end{tabular}

Table 4: Measured spray spectra characteristics for different testes of Proptec $^{\mathrm{TM}}$ rotary atomizer at different tests.

\begin{tabular}{ccccc}
\hline Treatment & $\begin{array}{c}\text { Flow-rate, } \\
1 \mathrm{~min}^{-1}\end{array}$ & $\begin{array}{c}\mathrm{D}_{\mathrm{v} 0.1} \\
\mu \mathrm{m}\end{array}$ & $\begin{array}{c}\mathrm{D}_{\mathrm{v} 0.5} \\
\mu \mathrm{m}\end{array}$ & $\begin{array}{c}\mathrm{D}_{\mathrm{v} 0.9} \\
\mu \mathrm{m}\end{array}$ \\
\hline Proptec $^{\mathrm{TM}}$ (3000 r.p.m) & 0.5 & 71.78 & 100.17 & 139.61 \\
Proptec $^{\mathrm{TM}}$ (3000 r.p.m) & 1.0 & 76.51 & 98.59 & 125.41 \\
Proptec $^{\mathrm{TM}}$ (3500 r.p.m) & 0.5 & 51.27 & 92.28 & 128.57 \\
Proptec $^{\mathrm{TM}}$ (3500 r.p.m) & 1.0 & 70.20 & 90.71 & 122.26 \\
Proptec $^{\mathrm{TM}}$ (4600 r.p.m) & 0.5 & 63.89 & 81.24 & 109.64 \\
Proptec $^{\mathrm{TM}}$ (4600 r.p.m) & 1.0 & 57.58 & 76.51 & 104.90 \\
Proptec $^{\mathrm{TM}}$ (5000 r.p.m) & 0.5 & 41.80 & 65.47 & 104.90 \\
Proptec $^{\mathrm{TM}}$ (5000 r.p.m) & 1.0 & 35.49 & 62.31 & 108.06 \\
\hline
\end{tabular}


Table 5: Measured spray spectra characteristics for different testes of five EMTF nozzles different tests.

\begin{tabular}{ccccc}
\hline & Flow-rate, & $\mathrm{D}_{\mathrm{v} 0.1}$ & $\mathrm{D}_{\mathrm{v} 0.5}$ & $\mathrm{D}_{\mathrm{v} 0.9}$ \\
EMTF nozzles & $1 \mathrm{~min}^{-1}$ & $\mu \mathrm{m}$ & $\mu \mathrm{m}$ & $\mu \mathrm{m}$ \\
\hline N 1 ( Lechler FT 5 - 608 + TT110-05 POM) & 0.5 & 71.6 & 174.0 & 284.8 \\
N 1 ( Lechler FT 5 - 608 + TT110-05 POM) & 1.0 & 89.7 & 204.0 & 416.9 \\
N 2 ( Lechler FT 5 - 608 + AD120-04 POM) & 0.5 & 57.2 & 137.8 & 262.9 \\
N 2 ( Lechler FT 5 - 608 + AD120-04 POM) & 1.0 & 62.1 & 145.5 & 241.1 \\
N 3 ( Lechler FT 5 - 608 + LU120-015 & 0.5 & $\mathbf{4 2 . 7}$ & $\mathbf{1 0 0 . 9}$ & $\mathbf{1 9 5 . 4}$ \\
POM) & & & & \\
N 3 ( Lechler FT 5 - 608 + LU120-015 & 1.0 & $\mathbf{5 2 . 6}$ & $\mathbf{1 2 5 . 5}$ & $\mathbf{2 2 9 . 4}$ \\
POM) & & & & \\
N 4 ( Lechler FT 5 - 608 + DG8003 VS) & 0.5 & 58.5 & 128.0 & 250.3 \\
N 4 ( Lechler FT 5 - 608 + DG8003 VS) & 1.0 & 72.9 & 162.1 & 272.6 \\
N 5 ( Lechler FT 5 - 608 + XR8004VK) & 0.5 & $\mathbf{4 6 . 7}$ & $\mathbf{1 0 7 . 0}$ & $\mathbf{2 0 6 . 1}$ \\
N 5 ( Lechler FT 5 - 608 + XR8004VK) & 1.0 & $\mathbf{5 6 . 0}$ & $\mathbf{1 2 2 . 6}$ & $\mathbf{2 1 3 . 4}$ \\
\hline
\end{tabular}

Table 6: The comparisons average values of spray spectra characteristics for different low-pressure liquid atomizers

\begin{tabular}{|c|c|c|c|c|}
\hline ATOMIZER\$ & $\begin{array}{c}\text { Flow-rate, } \\
1 \text { min- }^{1}\end{array}$ & $\begin{array}{c}D_{\mathrm{v} 0.1} \\
\mu \mathrm{m}\end{array}$ & $\begin{array}{c}\mathrm{D}_{\mathrm{v} 0.5} \\
\mu \mathrm{m}\end{array}$ & $\begin{array}{c}\mathrm{D}_{\mathrm{v} 0.9} \\
\mu \mathrm{m}\end{array}$ \\
\hline N1 & 1.0 & 80.6 & 189.0 & 350.7 \\
\hline $\mathrm{N} 2$ & 1.0 & 59.6 & 141.6 & 252.0 \\
\hline N3 & 1.0 & 47.5 & 113.1 & 212.5 \\
\hline N4 & 1.0 & 65.5 & 145.1 & 261.4 \\
\hline N5 & 1.0 & 51.3 & 114.7 & 209.8 \\
\hline Mistblower (3000 r.p.m) & 1.0 & 40.0 & 101.0 & 175.0 \\
\hline Mistblower (4000 r.p.m) & 1.0 & 37.0 & 92.4 & 164.3 \\
\hline Mistblower (5000 r.p.m) & 1.0 & 33.9 & 86.1 & 150.5 \\
\hline Mistblower (6000 r.p.m) & 1.0 & 29.8 & 77.5 & 129.2 \\
\hline Proptec $^{\mathrm{TM}} \quad$ (3000 r.p.m) & 1.0 & 74.1 & 98.3 & 132.5 \\
\hline Proptec $^{\mathrm{TM}} \quad$ (3500 r.p.m) & 1.0 & 60.6 & 91.4 & 125.3 \\
\hline Proptec $^{\mathrm{TM}} \quad$ (4600 r.p.m) & 1.0 & 60.5 & 78.8 & 107.0 \\
\hline
\end{tabular}




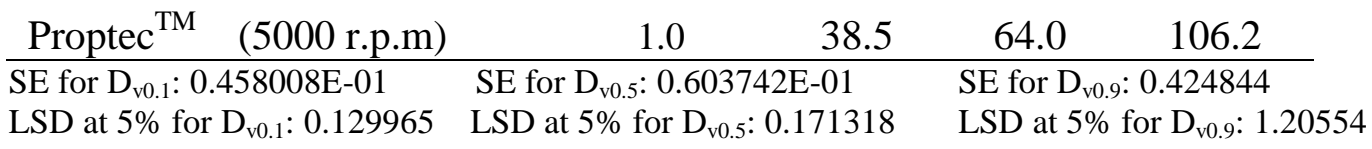

Table 7: Average values of the effect of flow/rate on spray spectra characteristics for different atomizers

\begin{tabular}{cccc}
\hline $\begin{array}{c}\text { Flow rate } \\
1 \text { min }-\end{array}$ & $\begin{array}{c}\mathrm{D}_{\mathrm{v} 0.1} \\
\mu \mathrm{m}\end{array}$ & $\begin{array}{c}\mathrm{D}_{\mathrm{v} 0.5} \\
\mu \mathrm{m}\end{array}$ & $\begin{array}{c}\mathrm{D}_{\mathrm{v} 0.9} \\
\mu \mathrm{m}\end{array}$ \\
\hline 0.5 & 49.4667 & 103.9 & 178.16 \\
1.0 & 55.0744 & 110.477 & 187.510 \\
\hline
\end{tabular}

SE for $\mathrm{D}_{\mathrm{v} 0.1}: 0.179645 \mathrm{E}-0 \quad$ SE for $\mathrm{D}_{\mathrm{v} 0.5}: 0.236807 \mathrm{E}-01 \quad$ SE for $\mathrm{D}_{\mathrm{v} 0.9}: 0.166638$

LSD at $5 \%$ for $\mathrm{D}_{\mathrm{v} 0.1}: 0.509763 \mathrm{E}-01 \quad$ LSD at $5 \%$ for $\mathrm{D}_{\mathrm{v} 0.5}: 0.671965 \mathrm{E}-01 \quad$ LSD at $5 \%$ for $\mathrm{D}_{\mathrm{v} 0.9}: 0.472852$

\section{Deposition percentage for different atomizers}

The deposit is a quantity of pesticide remaining on the target area immediately after applications, as well as, it is the function of the ability of sprayers to distribute the pesticide.

Figures 6 and 7 indicate that, the increasing of rotational speed for Proptec $^{\mathrm{TM}}$ rotary cage and Stihl mistblower tends to increase the deposition percentage at two flow-rate level 0.5 and $11 \mathrm{~min}^{-1}$. This result was agreement with Salyani and Hoffmann (1996). The Proptec ${ }^{\mathrm{TM}}$ rotary cage atomizer at rotational speed $5000 \mathrm{rpm}$ tend to give the best values (high values) of deposition comparing with the motorized Stihl mistblower and the five EMTF nozzles. Therefore, the Proptec ${ }^{\mathrm{TM}}$ cage atomizer produced a higher air volume $2300 \mathrm{~m}^{3} \mathrm{~h}^{-1}$ compared with the $8922300 \mathrm{~m}^{3} \mathrm{~h}^{-1}$ for Stihl mistblower and $3832300 \mathrm{~m}^{3} \mathrm{~h}^{-1}$ for EMTF nozzle as shown in table 2 . The higher air volume and very fine droplets size that produced by the Proptec ${ }^{\mathrm{TM}}$ rotary atomizer may be carried the droplet into the target and these tend to increase the deposition (Sehsah, 2005 and Sehsah, 2007). The highest values of deposition percentage for Proptec $^{\mathrm{TM}}$ rotary cage atomizer at flow rate $1.01 \mathrm{~min}^{-1}$ were $71.5 \%$ and $59.3 \%$ at rotational speed 5000 r.p.m and 3000 r.p.m respectively. As well as, the highest values of deposit percent for Motorized Backpack mistblower at $1.01 \mathrm{~min}^{-1}$ were $62.6 \%$ and $51.3 \%$ at rotational speed 6000 r.p.m and 3500 r.p.m., respectively.

The deposition percentage for Proptec ${ }^{\mathrm{TM}}$ rotary cage atomizer at maximum rotational speed 5000 r.p.m were $71.5 \%$ and $51.6 \%$ at flow rate $0.51 \mathrm{~min}^{-1}$ and $1.01 \mathrm{~min}^{-1}$, respectively. As well as, The deposition 
percentage for Motorized Backpack mistblower at maximum rotational speed 6000 r.p.m were $62.6 \%$ and $48.2 \%$ at flow rate $0.51 \mathrm{~min}^{-1}$ and $1.01 \mathrm{~min}^{-1}$, respectively.

The EMTF nozzles N3 (Lechler FT 5 - 608 + Lechler LU 120-015 POM) and N5 (Lechler FT 5 - 608 + Tee Jet XR8004 VK) tend to produce the best deposition percentage compared with the $\mathrm{N} 1, \mathrm{~N} 2$ and $\mathrm{N} 4$ nozzles as shown in figures 6 and 7. As well as, the EMTF nozzles N3 and N5 may be produced the deposition percentage values same as the deposition values for Proptec ${ }^{\mathrm{TM}}$ rotary cage and Stihl mistblower atomizers at flowrate $0.51 \mathrm{~min}^{-1}$ and $1.01 \mathrm{~min}^{-1}$.

The deposition percentage for N3 (Lechler FT 5 - 608 + Lechler LU 120015 POM) and N5 (Lechler FT 5 - 608 + Tee Jet XR8004 VK) were $57.7 \%$ and $58.8 \%$ at flow-rate $1.01 \mathrm{~min}^{-1}$. In addition, the deposition percentage for N3 (Lechler FT 5 - 608 + Lechler LU 120-015 POM) and N5 (Lechler FT $5-608+$ Tee Jet XR8004 VK) were $48.1 \%$ and $49.9 \%$ at flow-rate $0.51 \mathrm{~min}^{-1}$. It was non-significant different of the deposition percentage values between the Proptec ${ }^{\mathrm{TM}}$ rotary cage, Stihl Mistblower, N3 (Lechler FT 5 - 608 + Lechler LU 120-015 POM) and N5 (Lechler FT 5 - $608+$ Tee Jet XR8004 VK) at two flow-rate $0.51 \mathrm{~min}^{-1}$ and $1.01 \mathrm{~min}^{-1}$.

In addition, it noticed that the increasing of flow-rate tends to increase the deposition percentages for all atomizers under all treatment conditions.

\section{Sedimentation percentage for different atomizers}

Sediment is one of the important parameter that indicates the loss of pesticides on the soil. The motorized Mistblower and Proptec rotary cage at low rotational speed tend to give the low values of sedimentation comparing with the N1, N2 and N4 EMTF nozzles. On the other hand, the revolution speed $5000 \mathrm{rpm}$ for rotary atomizer tend to give the highest mean values of sediment comparing with the motorized Mistblower and five EMTF nozzles at two levels of flow-rate. This results agreement with Sehsah, et. al, (2004c).

The motorized Mistblower gave the low sediment compared with the Proptec rotary cage and the five EMTF nozzles. Therefore, the motorized Mistblower produced the highly air velocity that reduced the losses of the droplets compared with the Proptec cage atomizer as shown table 2. 
Figure 8 illustrates the increasing of both rotation speed and flow-rate tends to increase the total average of spray losses in the soil sediment. The total average of spray losses in the soil sediment for Proptec ${ }^{\mathrm{TM}}$ rotary atomizer at $3000 \mathrm{rpm}$ and flow-rate $0.51 \mathrm{~min}^{-1}$ was $13.6 \%$ comparing with $15.9 \%$ for rotary atomizer at $5000 \mathrm{rpm}, 9.3 \%$ and $12.2 \%$ for Backpack motorized Mistblower at $3500 \mathrm{rpm}$ and $6000 \mathrm{rpm}$ rotational speed, respectively. As well as, the spray losses in the soil sediment for rotary atomizer at $3000 \mathrm{rpm}$ and flow-rate $1.01 \mathrm{~min}^{-1}$ was $18.4 \%$ comparing with $24.8 \%$ for rotary atomizer at $5000 \mathrm{rpm}, 13.3 \%$ and $17.5 \%$ for Backpack motorized Mistblower at $3500 \mathrm{rpm}$ and $6000 \mathrm{rpm}$ rotational speed, respectively.

The EMTF nozzles N3 (Lechler FT 5 - 608 + Lechler LU 120-015 POM) and N5 (Lechler FT 5 - 608 + Tee Jet XR8004 VK) tend to produce the best values of sedimentation percentage compared with the N1, N2 and N4 nozzles as shown in figure 8 . The type of nozzles was a highly effect on the sedimentation percentage and this result was agreement with Sehsah (2007).

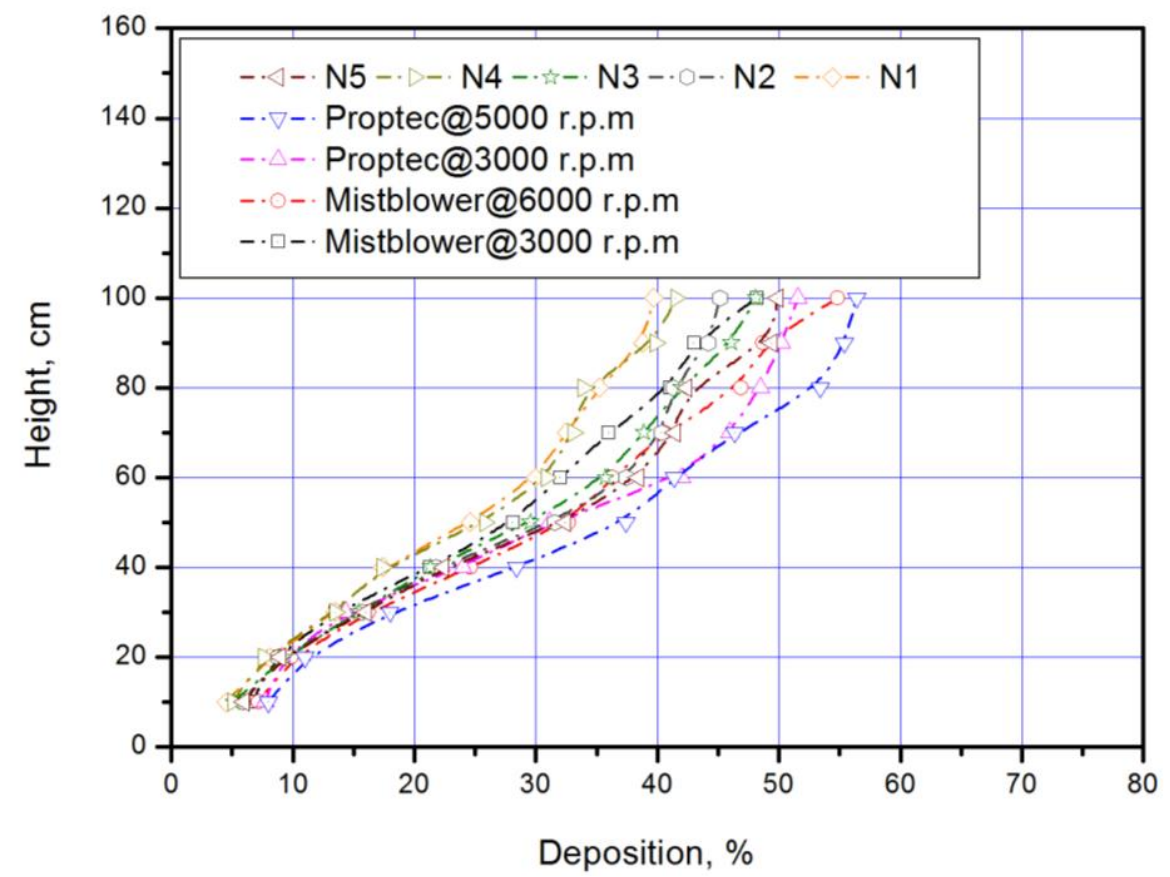

Fig. 6: The deposition for the Backpack mistblower, rotary cage Proptec TM and different five EMTF nozzles at flow-rate $0.51 \mathrm{~min}^{-1}$ 


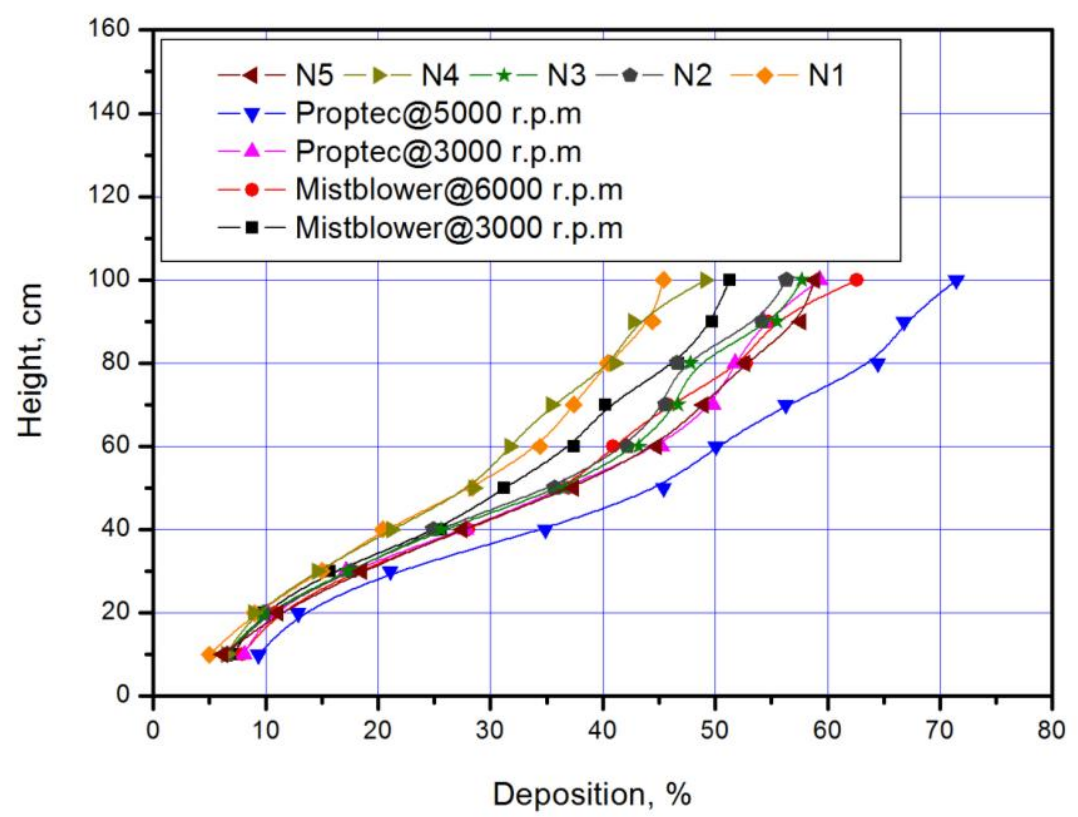

Fig. 7: The deposition percentage for the Backpack Mistblower, Proptec ${ }^{\mathrm{TM}}$ rotary and different five EMTF nozzles at flow-rate $1.01 \mathrm{~min}$

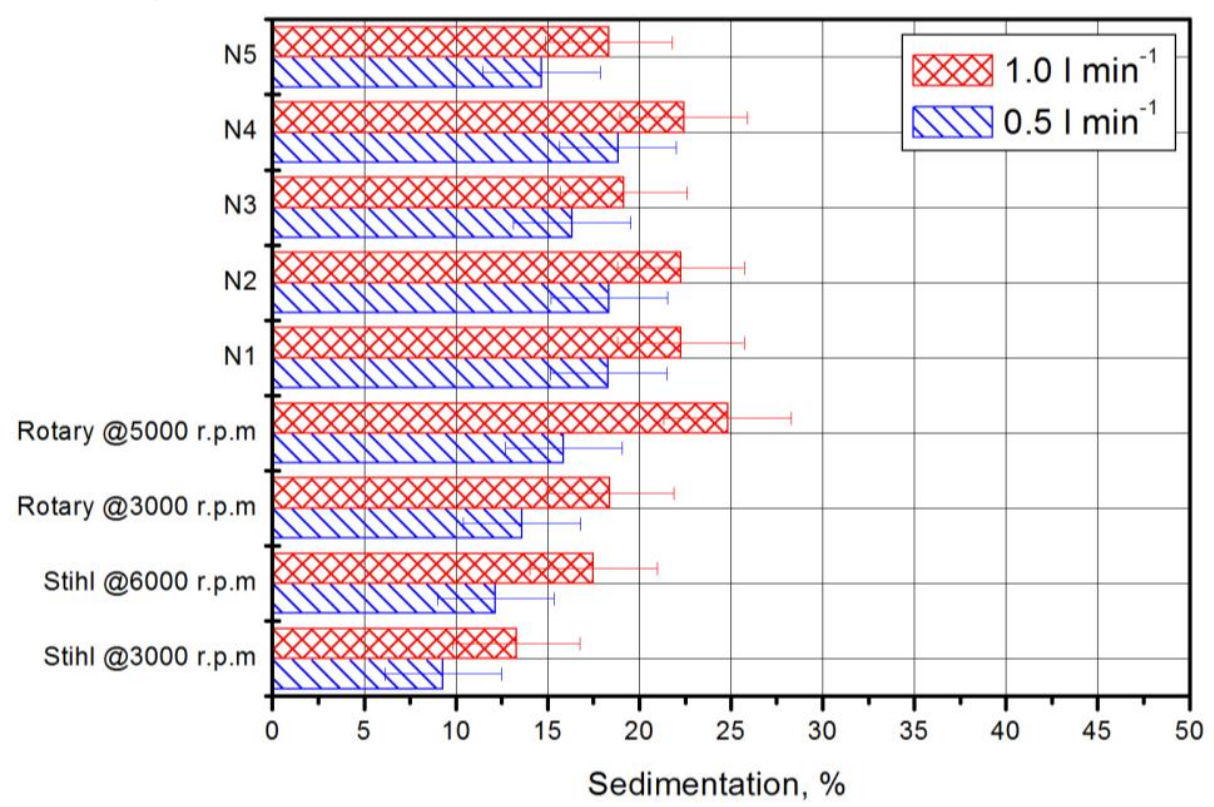

Fig. 8: The sedimentation percentage for the Backpack mistblower, Proptec $^{\mathrm{TM}}$ rotary cage and different five EMTF nozzles at two flowrate $0.51 \mathrm{~min}^{-1}$ and $1 \mathrm{~min}^{-1}$ 
As well as, the EMTF nozzles N3 and N5 gave the low sedimentation percentage values compared with Proptec ${ }^{\mathrm{TM}}$ rotary cage at two flow-rate levels and rotational speed 5000 r.p.m. as shown in figure 8. These due to the N3 and N5 EMTF nozzles have not any spray turbulence compared with the Proptec ${ }^{\mathrm{TM}}$ rotary atomizer. As well as, the EMTF nozzles produced higher air shear velocities that tend to reduce the spray losses in sedimentation on the soil. The sediment percentage for N3 (Lechler FT 5 - 608 + Lechler LU 120-015 POM) and N5 (Lechler FT 5 - 608 + Tee Jet XR8004 VK) were $16.3 \%$ and $14.6 \%$ at flow-rate $0.51 \mathrm{~min}^{-1}$. In addition, the sediment percentage values for N3 (Lechler FT 5-608+ Lechler LU 120-015 POM) and N5 (Lechler FT 5 - 608 + Tee Jet XR8004 VK) were $19.2 \%$ and $18.3 \%$ at flow-rate $1.01 \mathrm{~min}^{-1}$.

\section{CONCLUSION}

The results shown here demonstrate highly significant effect of the combinations of nozzles on the spray spectra, deposition and sedimentation through to be important in the selection of the EMTF nozzles. It's found that the all five EMTF nozzles gave very fine spray spectra at low flow rate $0.51 \mathrm{~min}^{-1}$. This means also, it was no different spray spectra values between the EMTF nozzles and both motorized mistblower and hydraulic rotary atomizers at low flow rate. The Proptec $\mathrm{TM}$ rotary atomizer gave a very fine spray spectra compared with the motorized mistblower and the five EMTF nozzles. All treatment indicate that mean droplet size diminishes with increasing rotational speed and increases with liquid flow rate. The deposition percentage for Proptec ${ }^{\mathrm{TM}}$ rotary cage atomizer at maximum rotational speed 5000 r.p.m were $71.5 \%$ and $51.6 \%$ at flow rate $0.51 \mathrm{~min}^{-1}$ and $1.01 \mathrm{~min}^{-1}$ respectively. As well as, the EMTF nozzles N3 and N5 may be produced the deposition percentage values same as the deposition values for Proptec rotary cage and Stihl mistblower atomizers at flow-rate $0.51 \mathrm{~min}^{-1}$ and $1.01 \mathrm{~min}^{-1}$. It was non-significant different of the deposition percentage values between the Proptec ${ }^{\mathrm{TM}}$ rotary cage, Stihl Mistblower, N3 (Lechler FT 5-608+ Lechler LU 120-015 POM) and N5 (Lechler FT 5 - 608 + Tee Jet XR8004 VK) at two flow-rate $0.51 \mathrm{~min}^{-1}$ and $1.01 \mathrm{~min}^{-1}$. The motorized Mistblower gave the low sediment compared with the Proptec rotary cage and the five EMTF nozzles. The increasing of both rotation speed and 
flow-rate tends to increase the total average of spray losses in the soil sediment. The N3 and N5 EMTF nozzles gave the low sedimentation percentage values compared with Proptec ${ }^{\mathrm{TM}}$ rotary cage at two flow-rate levels and rotational speed 5000 r.p.m. It may be able to produce the finest droplet without increase the energy and costs. In addition, the low pressure application is of advantage. It reduces wear, saves energy and spares the equipment.

\section{Acknowledgment}

The author would like to extend their thanks to Dr.Bäcker in federal research center, Geisenheim, Germany specially for sponsoring this work, together with assistance from Dr. Robert Heinkel in Lechler Company.

\section{REFERENCES}

Bateman, R.P. and R.T. , Alves .2000. Delivery systems for mycoinsecticides using oil-based formulations. Aspects of Applied Biology, 57, 163-170.

Heinkel R., A. Fried and E. Lange (2000): Einsatz grobtropfiger IDInjektor-Flachstrahl-Düsen in Apfelkulturen. MonatsschriftMagazin für den Gartenbau-Profi 4/2000.

Hoffmann, W.C. and M. Salyani (1996): Spray deposition on citrus canopies under different meteorological conditions. Transactions of ASAE 39(1):17-22.

Knewitz H., H. Koch and F. Lehn (2000): Abdriftreduzierung mit grobtropfigen Düsen. Obstbau, 2/2000: 77-82.

Pergher, G. and R. Gubiani (1995): The effect of spray application rate and airflow rate on foliar deposition in a hedgerow vineyard. J. Agric. Eng. Res. 61:205-216.

Peterson, D.L. and H.W. Hogmire (1994): Tunnel sprayer for dwarf fruit trees. Transaction of ASAE 37(3):709-715.

Salyani, M. (1994): Spray deposition and drift from air-carrier sprayers. AGENG94. Report N.94-D- 149.

Schmidt K. and H. G. Funke (2001): Abdriftarmer Pflanzenschutz im Obstbau. Obstbau, 3/2001: 125-153.

Sehsah, E., G. Baecker and S. Kleisinger (2004c): Evaluation of an experimental sprayer with rotary atomizers by air characteristics, soil sedimentation, deposition and vertical drift. International 
Conference Environmentally Friendly Spray Application Techniques 4-6 October, 2004c - Warsaw, Poland.

Sehsah E.M.E. (2005): Application techniques for biological crop protection in Orchards and vineyards. Ph.D thesis, Hohenheim University, ISDN: 3-86186-484-3 Vorlag Grauer Stuttgart Germany.

Sehsah E.M.E. (2007): Study effect of forward speed and nozzles types on spray characteristics of air assistance hydraulic sprayer, Misr J.Ag.Eng., 24 (1): 75-87.

Sehsah E.M.E. and S. Kleisinger (2007): Effect of low pressure liquid atomizers usage in biological pest control, Misr J.Ag.Eng., 24 (1): 62-74.

Siegfried, W. and E. Holliger (1996): Application technology in fruitgrowing and viticulture. Field Trial Report, Swiss Federal Research Station, International Society for Horticultural, $111 \mathrm{pp}$.

Teske, M.E., H.W. Thistle, A.J. Hewitt, I.W. Kirk, R.W. Dexter and J.H. Ghent (2005): Rotary atomizer droplet size distribution database. Journal of Transaction, ASAE., 48 (3): 917-921.

Walklate, P.J. (1992): A simulation study of pesticide drifts from an airassisted orchard sprayer. J. Agric. Eng. Res. 51:263-283.

\section{الملخص العربي}

خصائص الرش والترسيب والتغطية للمرذيذات ذات الضغط المنخفض التريع

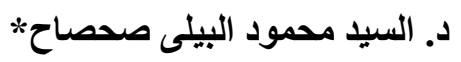

أجريت هذه الدر اسـة بمركز البحوث الفيدر الىـ قسم الميكنة الزر اعية بمدينـة جيزنهايم بألمانيا

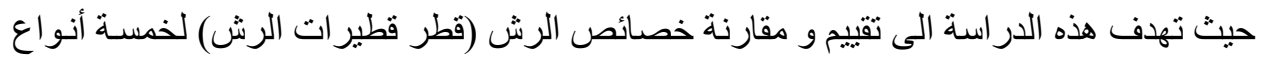

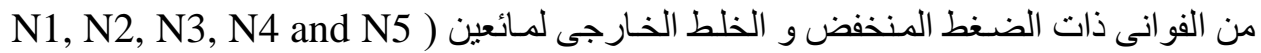

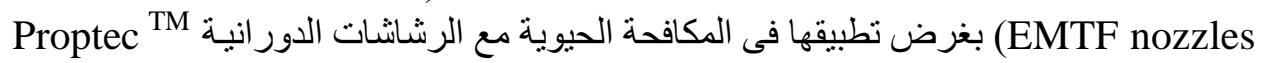
Rotary atomizer

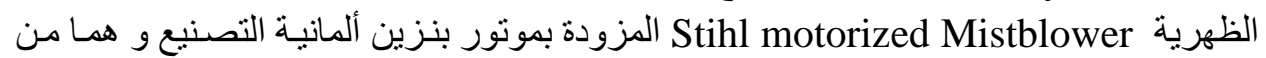

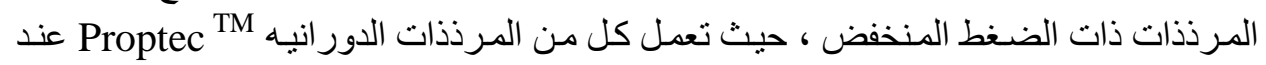

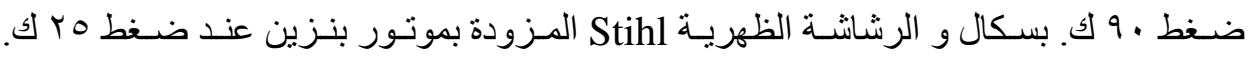

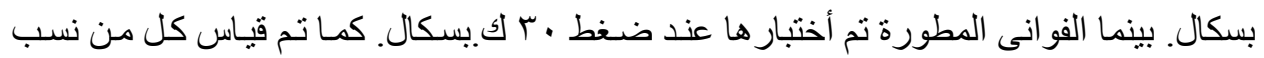

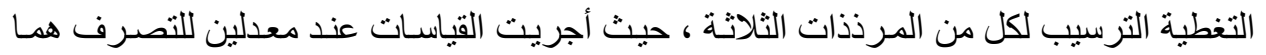
0.5 لتز /دقيقة و 1.0 لتر/دقيقة لكل من المرذذات المستعملة فى هذه الدراسة.

* مدرس بقسم الهندسة الزر اعيةـ كلية الزر اعةـ جامعة كفر الثيخ- مصر. 
كما تم قياس التغطية و الترسيب لكل من المرذذات الدور انيههـ هotorized Mistblower

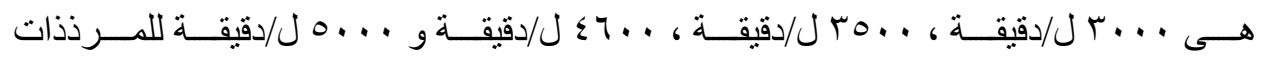

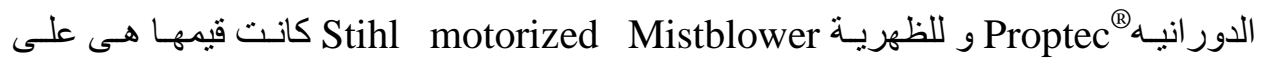

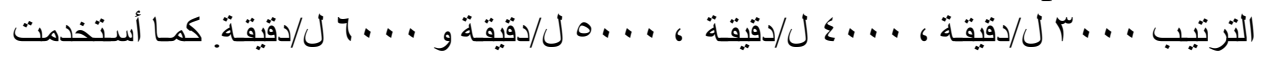

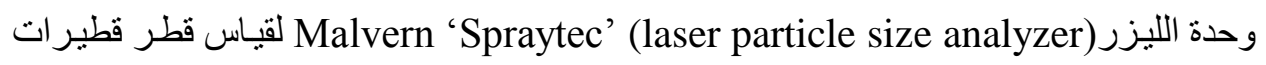

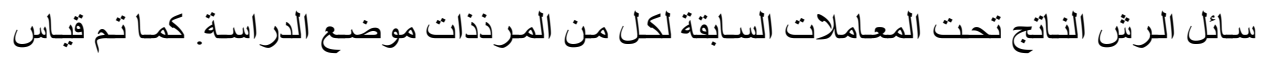

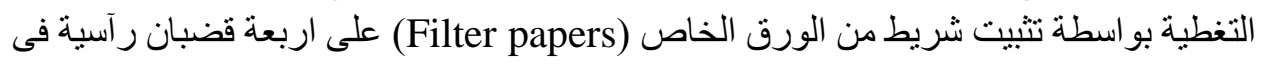

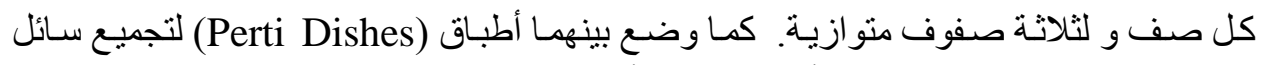

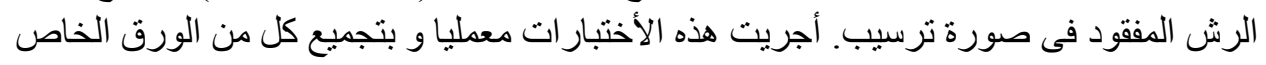
(Ferti Dishes) حيث تم تحليل و قياس نسب التغطية و الترسيب (Filter papers)

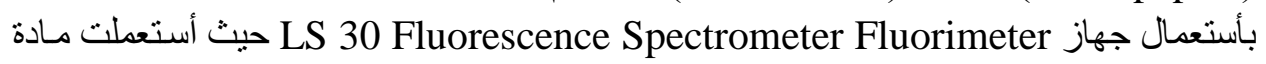
BSF فى سائل الرش بتركيز ا, , \% و التى يوصى باستعمالها عند اجر اء تلك الأختبار ات.

\section{أهم النتائج المتحصل عليها:}

وجد أنه بزيادة السرعة الدور انية لكل من المرذذات الدور انيهـ Proptec

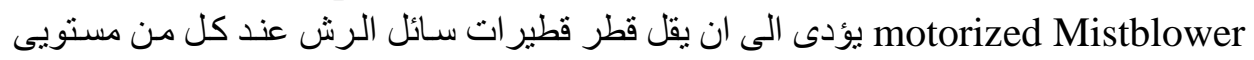

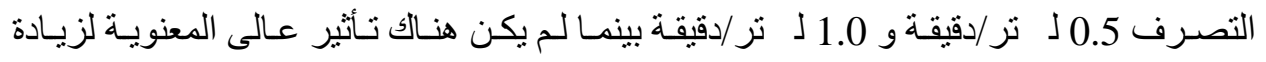

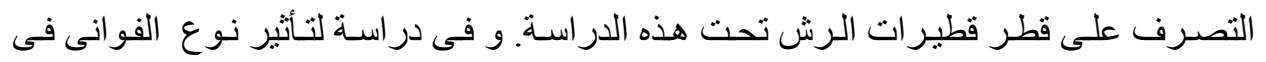

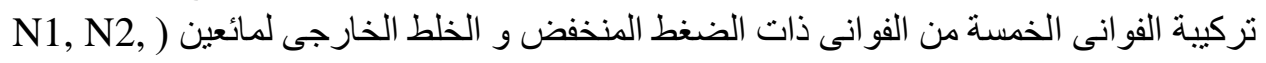

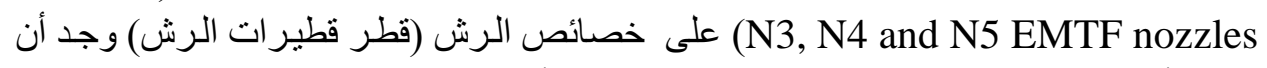

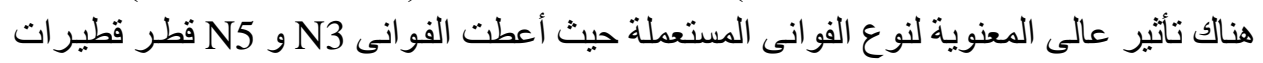
Proptec ${ }^{\text {TM }}$

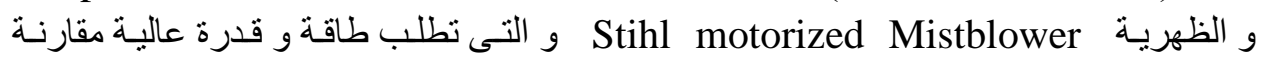

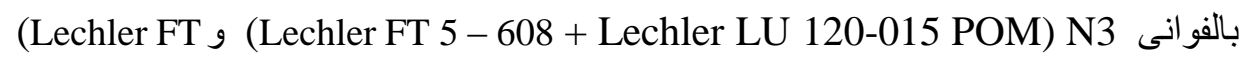
و 608 + Tee Jet XR8004 VK) N5 5 - 5 التى لا تحتاج الى طاقة او قدرة عالية فى تشغيلها.

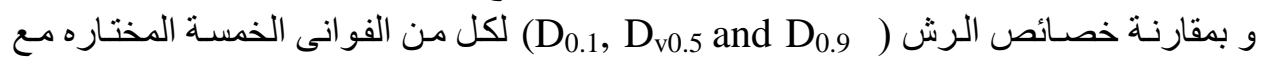

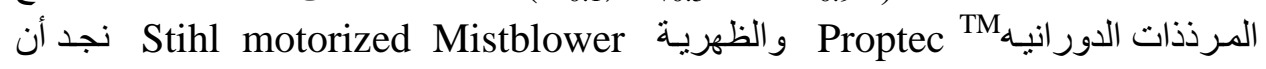

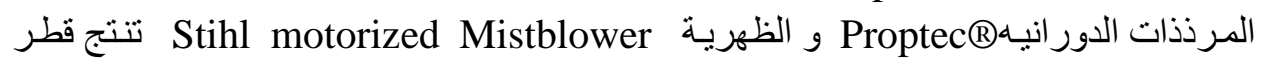

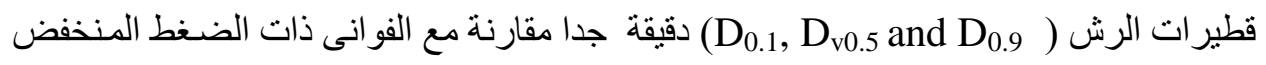

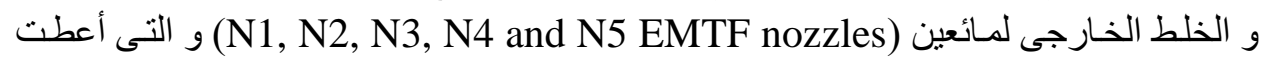

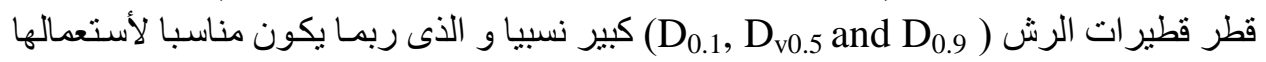

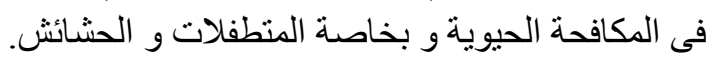

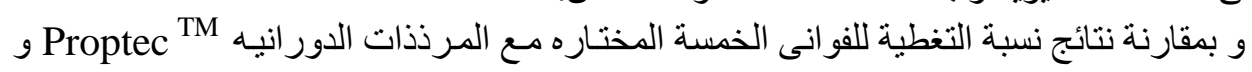

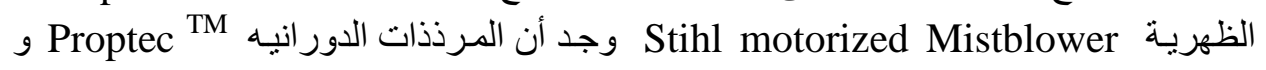


الظهريـة Stihl motorized Mistblower تنتج نسبة تغطية عالية مقارنة مع الفوانى ذات الضغط المنخفض و الخلط الخـارجى لمـائعين ) N1, N2, N3, N4 and N5 EMTF

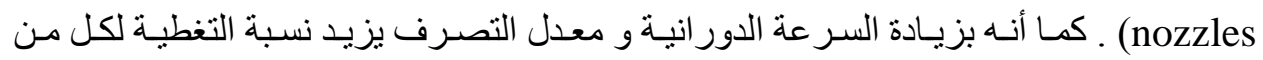
المرذذات الدور انيه ${ }^{\text {PM }}$

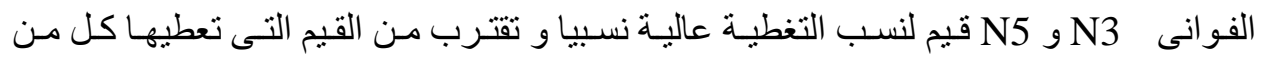

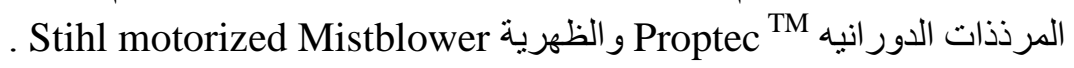

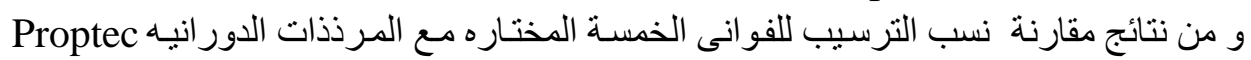

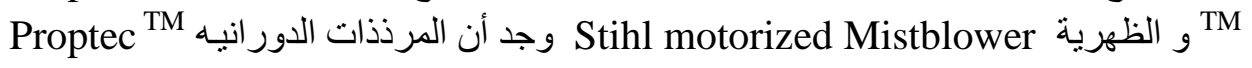
تنتج نسب للترسيب عالية مقارنة مـع الفوانى ذات الضغط المنخفض و الخلط الخـارجى لمـائعين عند معدل التصرف 1.0 لـ تر/دقيقة .كمات كمان (N1, N2, N3, N4 and N5 EMTF nozzles)

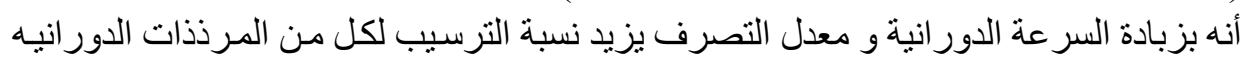

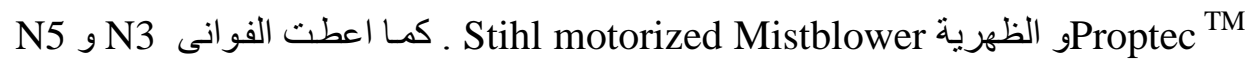

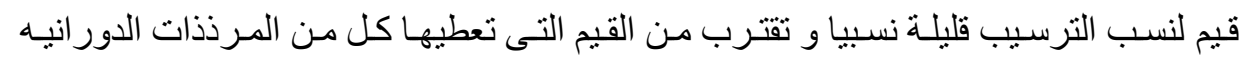

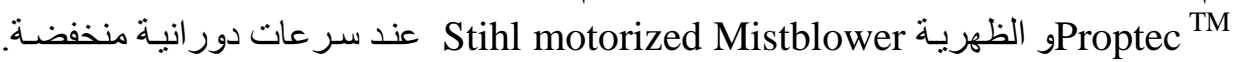

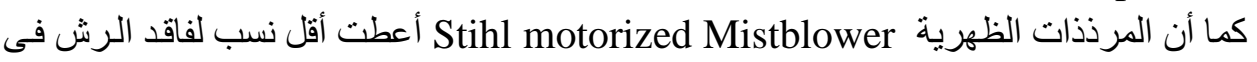

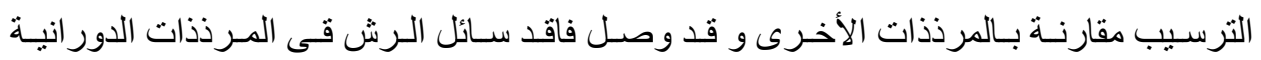

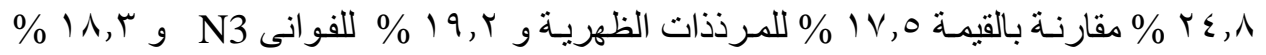

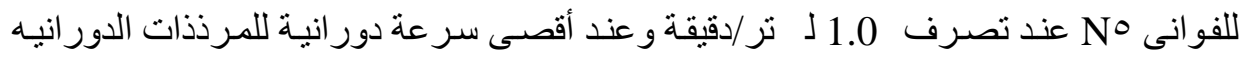

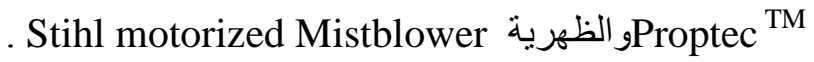

